\title{
Implementation of Life Skill Education in Learning on Entrepreneurship Character Development Through Blended Learning (Case Study of Students of Grade V SDN 1 Babakan)
}

\author{
Gita Amalia Firdhausi \\ $\{$ gitamalia235@gmail.com $\}$ \\ Universitas Muhammadiyah Purwokerto
}

\begin{abstract}
Implementation of life skills education in learning can develop and grow entrepreneurial character through blended learning during the learning period from home. In the situation of learning from home during the COVID-19 pandemic, inculcating life skill education in learning with blended learning is very necessary to foster the entrepreneurial character of students. This paper conveys the results of research with a qualitative descriptive approach regarding the implementation of life skills education in learning towards the development of entrepreneurial character through blended learning in time to study from home. This research was conducted at State Elementary School 1 Babakan, Kalimanah, Purbalingga Regency, Central Java, Indonesia. Data collection techniques used in this research are observation, interviews, and documentation. Data analysis uses the three-step model of Miles and Huberman, namely data reduction, data presentation, and concluding.
\end{abstract}

Keywords: Life Skill, Entrepreneurial Character, Blended Learning

\section{Introduction}

The purpose of national education in Article 3 of Law number 23 of 2003 concerning the National Education System is to function to develop capabilities and shape the character and civilization of a dignified nation in the context of educating the nation's life, aiming to create the potential of students to become human beings who believe and fear God Almighty. To be a noble character, healthy, knowledgeable, capable, creative, independent, a democratic people, and responsible citizen [1]. Based on these educational objectives, it concluded that through education create, innovative, productive, and characterful human beings can be so that education graduates can compete in the era of globalization which is full of challenges in the development of science, communication technology, and various other fields.

To realize the educational goals, educators are in need, who are responsible for the implementation of education. Educators must equip students by instilling and strengthening character education and life skills (life skills or life competencies) under the needs of the environment and the students themselves. Especially in the era of globalization in the 21 st century, with the advancement of technology. People are required to have various skills and life skills to be able to compete with society globally. Based on Trilling and Fadel in Hudian et al., there are three 21 st century educational skills. These skills are life and career skills, learning and innovation, and information media and technology skills. Those life Skills 
summarized to the scheme called rainbow-knowledge skills of the 21 st century or the $21^{\text {st }}$ century knowledge skills rainbow [2].

According to the Ministry of Education and Culture, strengthening character education in school can foster students' character, which is: think critically, creatively, able to communicate and collaborate, who can compete in the 21 st century [1]. These are under the four competencies that must-have by students in the 21 st century called $4 \mathrm{C}$, namely Critical Thinking and Problem Solving, Creativity, Communication Skills, and Ability to Work Collaboratively [2].

The existence of life skills education in schools is a hope to stimulate, motivate, and develop the entrepreneurial character of students from an early age [3]. In the current era of globalization, people already have received various advantages to seek and obtain opportunities. Thus, the school's job is to foster, motivate, and develop the entrepreneurial character of students with life skills.

Good learning is learning that can optimize the potential of students and can build life skills as a provision for students to live in society later. Thus, schools can produce individuals who are competent and have the skills needed to be able to compete in a global, especially during a pandemic where the world economy is changing [4].

As educators, in the future, the current pandemic demands to be creative to keep providing education life skills in learning online or offline. The existence of online learning has made student learning time automatically reduced [4]. So after online learning is complete, the question arises of what students will get and do to develop their potential.

This problem is the main focus of researches at Babakan 1 State Elementary School. The researcher wants to describe how the implementation of life skill education in blended learning (online and offline) towards developing entrepreneurial character during the study from the home period. Therefore, the researcher took the title "Implementation of Life Skills Education in Learning Towards Entrepreneurial Character Development During Learning From Home With Blended Learning (Case Study of Grade V Students of State Elementary School 1 Babakan).

\section{Literature Review}

\subsection{Life Skills Education}

The learning activities students as much as possible get a learning experience. The learning experience is a series of activities that must be done and done by students in sequence to achieve learning indicators and essential competencies. Providing learning experiences to students refers to the four pillars of education developed by UNESCO, namely: learning to know, learning to do, learning to be yourself (learning to be), and learning to live together. Then these pillars developed into the concept of life skills-based learning.

Life skills are the development of skills by students to carry out life as individual beings, social beings, and creatures of God. An education life skill is education to provide practical skills provision, in use, is associated with the potential possessed. Education is not only about achieving knowledge, but there must be a process of developing specific skills, attitudes, and values that are possible to apply in life [2][5].

Life skills are abilities that develop specific skills, attitudes, and values that can reflect in the life of the students in the future [3]. According to Malahayati and Rasyid, life skill education is the education that is oriented to equip student skills regarding the realm of knowledge and attitudes, as well as skills related to student development [6].

According to the article above, life skill indicators and sub-indicators include proficiency recognize themselves (sub-indicators: the appreciation of ourselves as creatures of God, aware 
and grateful for my shortcomings), ability to reason (sub-indicators: remember, imagine, classify, comparing, evaluating, and analyzing), social skills (sub-indicators: cooperation, responsibility, controlling emotions, interaction, managing conflict, participating, cultivating sportsmanship, discipline, and healthy living, listening, speaking, reading, writing opinions, and leading), and vocational skills (sub-indicators: basic movement, and producing goods or services) [1]

Based on some of the meanings of life skills above, we can conclude that life skills education is the education that optimizes the ability or potential of students by developing skills, attitudes, knowledge, and values that possibly can apply in the future. Life skill education does not prioritize aspects of understanding only, but rather a combination of all elements needed by students to live and compete in the future [2].

Life skill indicators are self-awareness skills, analytic thinking skills, social skills, and vocational skills. These aspects can be a provision, especially for students to develop the potential contained in students [7]. They can be a provision for the formation of the character of students later. The implementation of life skill education is an integrated manner in learning. There are several ways to develop life skills education. The following is the development of life skills through the following pathways: all subjects, separate subjects, self-development, programs for each level of education [12].

According to Anwar, the characteristics of learning life skills are as follows [5]: (1) The occurrence of the process of identifying learning needs; (2) There is awareness to work together; (3) The occurrence of alignment of learning activities to develop themselves, understand, independent business, a joint effort; and (4) There is a process of mastering personal, social, vocational, academic, managerial, entrepreneurial skills.

\subsection{Character building}

According to Kesuma et al., character education is an effort to educate children to make wise decisions and practice them in everyday life to help them contribute positivity to their environment [8]. Then, Samani and Hariyanto stated character education is a system of teaching character values to students which consists of components of knowledge, awareness or willingness, and action to implement these values, both to God, oneself, others, the environment, and nationality to become human beings [9]. Meanwhile, according to Zubaedi, character education is a deliberate (conscious) effort to realize virtue, namely objectively qualified humans, not only for individuals but also good for society. So we can conclude that character education is a conscious effort made to internalize character values to be practiced in their daily lives to improve their quality for themselves and others.

\subsubsection{Entrepreneurial Character}

Entrepreneurship is essentially an expression of one's soul through the attitude and behavior of creative and innovative ways to perform an activity [11]. Then, Suryana stated entrepreneurship is a discipline that studies the values, abilities, and behavior of a person is facing life's challenges and how to obtain opportunities with various risks that they may face [13]. Entrepreneurship is a separate discipline, has a systematic process, and is applied using creativity and innovation. So, the dynamic, risky, creative, and growth-oriented response, which is the innovation process, is a demonstration of entrepreneurial behavior [14].

\subsubsection{Characteristics of Entrepreneurship}

Nurkamelia Mukhtar and Munip suggested several entrepreneurial characters as follows [15]: (a) confident and optimistic, which has strong self-confidence and does not depend on others, (b) task and result oriented, which needs achievement (needs achievement), profitoriented, have strong motivation, energetic, diligent, and steadfast, have the determination to 
work hard, and initiative, (c) dare to take risks and like challenges shown by the attitude of being able to take reasonable risks.

Entrepreneurship education must be followed by character education or value education so that students can follow or win a business competition [16]. It is more important that they understand entrepreneurial values, such as independent, creative, risk-taking, action-oriented, leadership, hard work, honest, disciplined, innovation, responsibility, cooperation, never give up, commitment, realistic, curiosity know, communicative, and motivation to succeed.

According to Zimmerer \& Scarborough, there some entrepreneurial characters, such as: commitment and sincerity; the desire to assume responsibility; self-confidence; creativity and flexibility; motivated to achieve success; future-oriented; goal-oriented; innovation and knowledge.

\subsection{Blended Learning}

Blended learning is a learning model that integrates traditional learning (face to face) and online learning using digital learning resources [18]. Meanwhile, Thorne revealed that blended learning represents opportunities to integrate innovative advancements and technologies provided by online learning with interaction and participation offered the best of traditional education [19]. Based on both definition, we can conclude that blended learning is learning that combines face-to-face (traditional) learning and online (digital) learning.

According to Driscoll, there are four concepts regarding blended learning, such as [20]: (1) Combining various web-based technologies; (2) Combination of different learning approaches (such as behaviorism, constructivism, cognitivism); (3) Combination of many formats of learning technology, such as videotape, CD-ROM, web-based training, film) with face-to-face learning; and (4) To create a good influence on learning and assignments, we can combine learning technology with an actual work assignment.

\section{Research Methods}

This research is descriptive qualitative research with a case study approach, namely analysis that provides an in-depth description of the problems in an object of research. Herdiansyah explains that a case study is an exact qualitative research model about an individual or a detailed qualitative research model about a particular individual or social unit over a certain period [21].

The data collection technique used in this study is the observation method on the object of observation in grade $\mathrm{V}$ both during online and offline learning. Interview with the Principal of State Elementary School 1 Babakan, and a grade V homeroom teacher. This research uses the data triangulation technique. In this research design, the triangulation technique used is source triangulation. The researcher tests the credibility of the data from one source to another by using source triangulation. Source triangulation was done by comparing data sources from class, teachers, and students in grade V. The researcher gets conclusions by analyzing existing data sources.

The data analysis was carried out using the theory of Miles, Huberman, and Saldana (2014), which analyzed the data using three steps, namely (1) data reduction, which was a process of selecting, focusing on simplification, abstracting, and transforming "rough" data that emerged from written notes at the research site. Data reduction continues - continuously for research activities oriented qualitative, (2) data (data display), is a collection of information that gives the possibility of drawing conclusions and taking action, (3) conclusion or verification, the researchers began to look for objects, noting the regularity, patterns, explanations, possible configurations of causal pathways, and propositions. 
To analyze the data, the researcher used the theory by Miles, Huberman, and Saldana [22], by using three steps: (1) data reduction, which is a selection process, focusing on simplification, abstraction, and transformation of "rough" data that emerges from written notes at the research site. Data reduction continues - continuously for research activities oriented qualitative. (2) Data (data display) is a collection of information that can usher the probability of drawing conclusions and taking action. (3) Deduction or verification, the researchers began to look for objects, noting the regularity, patterns, explanations, possible configurations of causal pathways, and propositions.

\section{Results and Discussion}

Based on an interview and observation with the homeroom teacher of grade $\mathrm{V}$ of State Elementary School 1 Babakan, NA, she stated that she referred to the characteristics of learning life skills by Anwar in her learning process. As she said in the interview, she has carried out the stages of the character of learning life skills in the learning process during direct observation. It can prove the similarities between the learning process in grade $\mathrm{V}$ of State Elementary School 1 Babakan with Anwar's learning life skills characteristics [5].

Before carrying out the lesson, the teacher makes a lesson plan. By planning to learn, she can carry out education according to the goals and desired results optimally. While identifying learning needs, she considers the current pandemic situation where students have to study from home. Therefore, she wants students to focus not only on knowledge aspects but also on life skills and cultivate an entrepreneurial character that is useful to look for future opportunities.

This life skill education leads to the growth of entrepreneurial character [5][11]. It is due to the situation and conditions during the pandemic, where children's learning time reduced, so she wants students at home to still optimize their potential. Therefore, she applies life skills education to foster entrepreneurial character in grade V of SES 1 Babakan by integrating character education and life skills education in each subject.

The success of education depends not only on the teacher/school and students but also on the role of parents. Therefore, she communicates regularly with parents to collaborate in the learning process to achieve learning objectives [3]. The collaboration is not limited only to cooperation in working on assignments or students' practice at home but also as a supervisor for student learning activities. In practice, all school members and student's guardians work collaboratively in strengthening character education. As reinforcement, we can make various activities inside or outside the classroom, at home, or in the community by involving the student's guardians.

In the learning process, the teacher, as much as possible, strengthens character education and inserts entrepreneurial character characteristics in the lesson plan, so blended learning is successfully oriented. Strengthen character education can instill life skills education [4-5]. The true entrepreneurial character is also related to the 18 character values formulated by the Ministry of National Education. The characteristics of entrepreneurship in question are independent, creative, risk-taking, action-oriented, leadership, hard work, honest, disciplined, innovative, responsible, cooperative, unyielding, commitment, realistic, curiosity, communicative, and motivation for success [14-16]].

The integration of character education in effective learning is to use a comprehensive approach [1][8]. The wisdom carried out is integrated into various subjects. The methods and strategies used are varied and have a probability for: set an example, the opposite of indoctrination, means of values, and soft skill development (effective communication, creativity, innovation, critical thinking, and problem-solving) [2][14]. 
The blended learning process carried out in the grade V of SES 1 Babakan, namely: 1) the teacher divides the material into two categories, independent learning material and guided/discussion with peers/teacher. 2) The teacher assigns the material to be studied independently at home with various online media. 3) The teacher continues to monitor the material periodically to ensure students do the assignments. 4) During face-to-face learning, the teacher repeats the material, conducts discussion and reinforcement, reflection and feedback, and guidance; 5) Teacher gives the following material. The cycle continues by adjusting the existing learning materials.

She uses various learning methods to optimize students' skills and characters, such as Contextual Teaching Learning (CTL), inquiry, and Cooperative Learning. Online learning in grade $\mathrm{V}$ at SES 1 Babakan uses Whatsapp groups. Learning practice also uses various media such as google classroom, quizzes, youtube, cap cut applications, Facebook, etc. Those media were familiar to students and had their charm to increase students' learning motivation.

The tasks given are simple practicum and projects. Some examples of these assignments are sketching batik drawings, doing simple experiments at home, making videos of singing the national anthem and regional anthems. Making illustration stories about the pandemic, drawing simple advertisements, doing interviews with economic communities, making a video of daily activities using cap cut application, self-study using youtube site, doing practice questions with quizzes and the google classroom learning application, etc. To find out student involvement in online learning, the teacher makes an absence system during online learning via the WA group and conducting online learning using zoom.

The various learning activities aim to provide learning experiences while strengthening students' character, especially to foster entrepreneurial nature [1][15]. The assignments will always be related to entrepreneurial characteristics to optimize the students' skills during the pandemic to channel the talents and interests of children who tend to prefer gadgets [. The distribution of talents and interests through various digital platforms helps find opportunities to compete and survive in society later.

Students carry out these learning activities accompanied by appropriate learning assessments [4]. It is needed to measure the students' ability shown by students during the learning process. Teacher conducts authentic assessments to measure students' abilities, such as attitude assessment (through observation, self-assessment, and journals), knowledge assessment (written tests and assignments), skills assessment (through performance assessment, project assessment, product assessment).

\section{Conclusion}

Based on the results and discussion of the researcher about the implementation of life skills education to foster entrepreneurial character through blended learning during the study at the home period at SES 1 Babakan, it can conclude as follows: (1) The teacher makes a learning plan for blended learning by referring to the characteristics of learning life skills and integrating character education, especially the entrepreneurial character in it; (2) She provides various learning methods that prioritize student activities and provide actual learning experiences. She also uses familiar technology-based media and the latest information for students (social media, youtube, cap cut application, quizzes, etc.) to optimize learning outcomes and objectives; (3) the teacher conducts the appropriate learning assessments suited to the learning activities to measure the students' actual abilities. The authentic assessment (attitudes assessment, knowledge assessment, and skills assessment) was use to acquire these goals; and (4) The results of the implementation of life skills education to foster entrepreneurial character through blended learning during the study at the home period in 
grade V at SES 1 Babakan went smoothly and succeeded in growing entrepreneurial character. These have a positive impact on increasing students' grades, attitudes, and skills. Students enthusiastically followed and did every assignment for work-making related to digital-mediabased-using and did simple practice skills at home.

\section{REFERENCES}

[1] Pramasanti R, Bramasta D, Anggoro S. IMPLEMENTASI PENDIDIKAN KARAKTER TANGGUNG JAWAB DAN KERJA SAMA DI DALAM PEMBELAJARAN TEMATIK KURIKULUM 2013 DI SD NEGERI 2 BERKOH. PENDAS MAHAKAM: Jurnal Pendidikan Dasar. 2020 Jun 14;5(1):35-40.

[2] Toheri T, Winarso W, Haqq AA. Three Parts of 21 Century Skills: Creative, Critical, and Communication Mathematics through Academic-constructive Controversy. Checker Similarity or Originality Universal Journal of Educational Research. 2019;7(11):1-6.

[3] Rosita T, Noor AH. URBAN FARMING IN THE CONTEXT OF INCREASING COMMUNITY WELFARE AND PARTICIPATION THROUGH THE WOMEN'S FARMERS GROUP (KWT) OF SAUYUNAN GARDENS COMMUNITY. EMPOWERMENT: Jurnal Ilmiah Program Studi Pendidikan Luar Sekolah. 2019 Oct $10 ; 9(1): 36-46$.

[4] Amalia RR, Anggoro S, Eka KI. Identification of Teachers and Students' Readiness to ELearning Implementation. JOURNAL OF TEACHING AND LEARNING IN ELEMENTARY EDUCATION (JTLEE); 4(2):170-9.

[5] Anwar. (2015). Life Skills Education (Life Skills Education. Bandung: Alphabeta.

[6] Malahayati M, Rasyid LM. The Role of North Aceh Government for Building Women's Capacity Based on Islamic Values in Vocational Village. Justicia Islamica. 2021 Feb 9;18(1):1-8.

[7] Lesmana W, Pardjono P. Need of vocational high school based on local potential for regional development in Cilacap District. Jurnal Pendidikan Vokasi. 2019 Mar 5;9(1):6374.

[8] Kesuma D, Triatna CE, Permana J. Character education (Study of Theory and Practice in Schools). Bandung: PT Remaja Rosdakarya. 2013.

[9] Samani M. Hariyanto. 2012. Konsep dan model pendidikan karakter. 2012;5.

[10] Zubaedi. Character Education Design: Its Conception and Application in Educational Institutions. Jakarta: Kencana Prenada Media Group. 2011.

[11] Suherman. Entrepreneurship Learning Design. Bandung: Alphabeta. 2008.

[12] Pardjono P, Suyanto W, Sofyan H, Wagiran W. What do Vocational Teachers, Industries, and Experts View about the Future Learning of Vocational Schools?. InInternational Conference on Indonesian Technical Vocational Education and Association (APTEKINDO 2018) 2018 Jul (pp. 250-255). Atlantis Press.

[13] Suryana. Entrepreneurship. Jakarta: Salemba Empat. 2014.

[14] Susilaningsih S. Konstruksi Model Program Pendidikan Kewirausahaan di Perguruan Tinggi: Pendekatan Sequential Exploratory Mixed Research Design Berbasis Multi Kasus.(Disertasi). DISERTASI dan TESIS Program Pascasarjana UM. 2012 Mar 2.

[15] AH NM, Munip A. Cultivating entrepreneurial values to improve several aspects of early childhood development: The case study in Khalifah Kindergarten Yogyakarta. Sunan Kalijaga International Journal on Islamic Educational Research. 2018;2(1):85-111. 
[16] Sari PO. Penerapan Pendidikan Kewirausahaan dalam Menumbuhkan Karakter Kewirausahaan Siswa DI SDN Kauman 1 Malang (Doctoral dissertation, University of Muhammadiyah Malang).

[17] Zimmerer TW, Scarborough NM. Essentials of entrepreneurship and small business management. Language. 2005;14(578p):28cm.

[18] Anggraeni H. Penguatan Blended Learning Berbasis Literasi Digital dalam Menghadapi Era Revolusi Industri 4.0. Al-Idarah: Jurnal Kependidikan Islam. 2019;9(2):190-203.

[19] Kurniawati R. Pengembangan Media Blended Learning Berbasis Edmodo di Sekolah Menengah Kejuruan. Indonesian Journal of Curriculum and Educational Technology Studies. 2015 Nov 30;3(2):16-24.

[20] Driscoll M. Blended learning: Let's get beyond the hype. E-learning. 2002 Mar;1(4):1-4.

[21] Herdiansyah, Haris. Qualitative Research Methods for the Social Sciences. Jakarta: Salemba Humanika. 2010.

[22] Miles, MB, Huberman, AM, \& Saldana, J. (2014). Qualitative Data Analysis, A Method Source Book, Edition 3, USA: Usage Publications. Translation of Tjetjep Rohindi Rohidi, UI-Press. 